Article

\title{
Lean Manufacturing and Environmental Sustainability: The Effects of Employee Involvement, Stakeholder Pressure and ISO 14001
}

\author{
Ping-Kuo Chen ${ }^{1}$, Itziar Lujan-Blanco ${ }^{2}$, Jordi Fortuny-Santos ${ }^{2}{ }^{\oplus}$ and \\ Patxi Ruiz-de-Arbulo-López ${ }^{3, *(\mathbb{D})}$ \\ 1 Department of Business Administration, Shantou University, Shantou 515063, China; \\ a1104100@ms23.hinet.net \\ 2 Department of Business Management, Universitat Politecnica de Catalunya, 08242 Manresa, Spain; \\ itziar.lujan@upc.edu (I.L.-B.); jordi.fortuny@upc.edu (J.F.-S.) \\ 3 Department of Business Management, University of the Basque Country (UPV/EHU), 48013 Bilbao, Spain \\ * Correspondence: patxi.ruizdearbulo@ehu.eus
}

Received: 30 July 2020; Accepted: 2 September 2020; Published: 4 September 2020

\begin{abstract}
This paper explores the relationships between lean manufacturing (LM), the promotion of green practices, employee involvement, pressure to take actions against environmental issues, the adoption of an ISO 14001-based environmental management system (EMS) and environmental performance in order to understand how LM can help improve environmental performance through environmental practices and the development of a lean culture. The effects of pressure to "go green", employee involvement and the adoption of an EMS based on the International Organization for Standardization's standard ISO 14001 are discussed. Data were collected from 220 Chinese manufacturing firms and analyzed using partial least squares (PLS) regression. The results suggest that the implementation of LM has a positive effect on the promotion of green practices and consequent achievement of high environmental performance; employee involvement is a moderator that affects the relationship between green practices and environmental performance; pressure to "go green" is a mediator in the relationship between LM and green practices; however, the adoption of ISO 14001 does not act as a moderator on the relationship between LM and green practices, but synergies emerge if ISO 14001 is integrated with LM. The study shows the importance of human attitudes and fosters managers to develop the necessary mechanisms to ensure and enhance employee involvement and lean culture. Although these determinants of environmental sustainability have been studied separately until now, this paper analyzes them simultaneously, investigating the relationship between different strategies and shedding some light on successful actions that promote sustainable manufacturing, and on the role of LM in sustainability. The findings can help manufacturers to take the initiative to improve environmental performance and assist governments in implementing industrial policies.
\end{abstract}

Keywords: lean manufacturing; employee involvement; ISO 14001; attitude; successful actions

\section{Introduction}

Since the Industrial Revolution, the manufacturing industry has developed rapidly, not only driving economic growth but also improving living standards. However, manufacturing activities require natural resources, water and energy and are also responsible for waste, air emissions and water pollution, threatening our environment [1] and contributing to climate change [2]. For this reason, manufacturing and environmental sustainability may be regarded as incompatible terms. However, within the research community, the paradigm of sustainable manufacturing is gaining acceptance and it is attracting the attention of practitioners as well [3]. The concept of sustainable manufacturing has 
evolved (see reviews in [3,4]) since the first studies based on environmentally conscious manufacturing and now it is defined as the creation of products that, throughout their life cycle, from the perspective of the triple bottom line, limit their negative impacts on Nature and society while offering economic and social value [5].

Currently, due to the implication of manufacturing in environmental issues (such as greenhouse gas emissions, resource depletion or water pollution), an increase in regulatory, social and economic pressure on manufacturers to "go green" (i.e., to become more environmentally friendly, improving their negative impact on the environment, in order to preserve the environment and the natural resources) is taking place. Determining how to promote sustainability as a response to such pressure is currently one of the most important issues being investigated in both theory and practice [6]. Neither technology nor management strategies can be ignored. Recent research shows that the aim to improve environmental performance (e.g., to minimize the consumption of energy in order to cut $\mathrm{CO}_{2}$ emissions) is difficult to achieve even with current best organizational practices [7]. For this reason, more research is necessary to understand the determinants of sustainable manufacturing and the relationships among different initiatives.

Companies respond to the pressure to "go green" through the promotion of green practices [8-10], which include efficient manufacturing processes as well as green procurement, green design (eco-design), and recycling. Through green practices, firms strive to improve their environmental performance levels [11,12]. However, Jabbour et al. [13] found that several barriers, including resistance to change, lack of training, aversion to innovation, limited financial capacity and the difficulty of establishing environmental awareness, may hinder the promotion of green practices and thus affect firms' green performance.

According to several studies [14-16], the implementation of lean manufacturing (LM) can overcome these barriers because LM is based on the elimination of "waste" (useless consumption of resources); it relies on the engagement of operators and it is made up of tools and techniques such as pull production, $5 S$ workplace organization method or total productive maintenance (TPM). All these elements promote green practices and contribute to a better environmental performance [17]. However, a few questions regarding the connections between $\mathrm{LM}$, green practices and environmental performance still need to be clarified. First, although many studies suggest that there is a connection between the "lean" and "green" concepts, and support this hypothesis with successful case studies, quantitative empirical studies that test the relationship between LM and environmental performance (such as [6] or [18]) are few and show mixed results [2,7]. Consequently, there is room for quantitative, survey-based empirical research. Second, LM possibly drives employee involvement and this should lead to positive effects on environmental performance. However, habits are hard to change and employees may have a lukewarm attitude towards LM [19] that may result in poor performance. Cherrafi et al. [20] state that companies face multiple barriers such as the lack of environmental awareness, resistance to change and lack of involvement. Improvement of employee involvement is deemed a factor to change habits and dismantle internal barriers. Thus, employee involvement seems to be a moderator-although this role needs to be clarified. Third, regulatory, social, and economic pressures greatly influence companies in their adoption of green practices [8]. Recent research [9] has empirically verified that both organizational and regulatory stakeholder pressures have direct influence on the adoption of green practices. However, their model did not consider the role of LM. In consequence, the existence of a mediating effect needs to be tested and clarified. Fourth, many companies implement environmental management systems (EMS) based on the requirements set by the International Organization for Standardization's standard ISO 14001 and some studies [21,22] suggest that LM and ISO 14001 can be integrated to achieve some synergies. However, the adoption of ISO 14001 standards requires intricate documentation and formalized processes [23]. In consequence, if the adoption of an EMS is combined with the requirements of $\mathrm{LM}$, the association may result in a complicated work process and lead to questionable results. Therefore, the adoption of an ISO 14001-based EMS may have a moderating effect 
on the relationship between the implementation of LM and the promotion of green practices. Again, this effect needs to be verified.

Based on the above, the research question that this paper addresses is: What are the relationships and effects between the following constructs: LM, the promotion of green practices, employee involvement, the pressure to "go green", the adoption of an ISO 14001-based environmental management system (EMS) and environmental performance? Although the literature is rich in publications on these determinants of environmental sustainability, they have been mainly studied in different research streams. However, no study has explored the relationship between them and specially the role of LM in relation to the other factors and their effects. Creating a framework that combines these variables and analyzing them together is the originality of this paper. This broad research question raises the four specific questions presented in the previous paragraph that are formulated as hypotheses to be tested by means of survey data through partial least squares (PLS) analysis so that the relationships or effects can be quantified. This paper contributes to the literature on successful actions that promote environmental sustainability on the following points: first, the study tries to empirically verify the relationship between LM, green practices, and environmental performance. Second, existing studies still point to a conflict among the roles of employee involvement, the pressure to adopt environmental practices and the adoption of ISO 14001. The research results can help managers understand the roles of these factors and guide them in establishing suitable practices to improve the environmental performance of their companies through LM.

\section{Literature Review and Theoretical Framework}

\subsection{Lean and Green}

Lean manufacturing (LM) is a business model rooted in the Toyota Production Systems (TPS) or "just-in-time" (JIT), as it was first known in Western countries [24]. In the 1980s, researchers at the Massachusetts Institute of Technology coined the term "lean" to describe the simplicity of some car assembly plants, with Toyota being the best example [25,26]. LM focuses on the elimination of everything that does not add value to the product and therefore it is considered a "waste" of resources (Muda in Japanese) [27] to deliver quality products at low cost with high productivity [28]. LM achieves its goals by means of many tools and techniques [29] that help identify, remove and prevent wasteful operations [30].

Despite the Japanese origins of LM, lean has won worldwide appreciation and, although it was conceived in the automotive industry, it is now adopted by a plethora of companies in manufacturing industries in order to improve their operational performance [2]. Beyond manufacturing, we find examples of the application of the principles of LM in healthcare, construction, or mining companies, to name a few sectors [6,31,32]. Womack et al. [26] believe that the fundamental ideas of LM are universal and advocate their adoption. Likewise, Ohno [27] warned those interested in Toyota's system to focus on the principles and adapt the operational routines. However, many companies fail to achieve a successful implementation [33].

In the 1990s, several scholars realized that there is a similitude between LM's battle against muda and the fight to reduce the environmental impact of the companies seeking to improve their environmental performance. They conceived the "lean and green" [34] hypothesis: Lean practices increase environmental performance [35] because the efforts to improve manufacturing processes to increase productivity create opportunities for environmental improvement [36]. LM being the most prominent paradigm in manufacturing [2], in recent years, the interest in the relationship between LM and environmental issues has flourished again and the number of published papers has skyrocketed $[37,38]$. However, there is still debate on the relationship between LM and environmental performance and, as summarized by Khodeir and Othman [39], while many papers defend different types of interaction between the two concepts, others state that LM is not "green" in essence because 
LM does not focus on environmental issues and therefore any environmental improvement is merely collateral and due to chance. Even for its defenders, the relationship is still a black box $[17,40]$.

Most papers on the "lean and green" hypothesis are either conceptual articles or case studies [41,42] but there is a lack of empirical works. Conceptual papers and reviews of the literature hold a positive correlation between LM and green practices (although some see conflicting differences in aspects such as replenishment frequency [43]) and case studies (see for example the action research example in [17]) report success stories and highlight the importance of adequate human-resource management as well. Empirical papers show mixed results: For example, LM enables organizations to adopt green practices, but LM alone does not have a significant impact on environmental performance [44], or LM improves a process in terms of quality but this negatively affects the environment [45]. Sartal el al. [7] show that companies where the reduction of carbon dioxide is paramount need to operate with higher levels of work-in-process, lead time, or workforce. Finally, Dieste el at. [46] undertake a review of the literature (many papers were not empirical) that shows that some environmental performance indicators are affected by the implementation of lean practices (especially air emissions, energy use and solid waste) although some studies concluded that the relationship with gas emissions may be negative. In recent reviews, Caldera et al. [47] and Farias et al. [40] associate different lean tools to environmental sustainability indicators and, in recent empirical research; Garza-Reyes et al. [18] empirically tested the relationship between LM and environmental performance in manufacturing companies; Sartal et al. [2] empirically showed, using data from Spanish manufacturers, that quality (jidoka) and respect for people positively affect environmental performance $\left(\mathrm{CO}_{2}\right.$ emissions), but there is a negative association between JIT manufacturing and $\mathrm{CO}_{2}$ emissions, showing that the principles of LM are not equally "green". Finally, Cherrafi et al. [6], based on survey data, tested the relationships between LM and environmental performance, green practices and environmental performance, and the effect of process innovation. However, they did not test whether green practices mediate the relationship between LM and environmental performance.

Jabbour et al. [13] empirically verified that several factors or barriers may hinder the adoption of green operational practices and affect firms' operational and green performance. Their study shows that internal barriers (including resistance to change, lack of training, aversion to innovation, limited financial capacity and the difficulty of establishing environmental awareness, among other factors) have greater impact than external barriers. When these impediments are not addressed, it is difficult to implement green practices and improve environmental performance. In addition, Babur et al. [48] suggest that LM might be implemented in order to change the attitudes (and associated behaviors and habits) of workers. We contemplate the following dynamics:

1. LM requires the engagement of operators $[15,26]$ in tasks such as problem-solving and process improvement. Otherwise, lean practices such as pull production $[15,29]$ with limited physical inventory would be impossible to achieve. Consequently, lean companies try to engage employees and change work habits by means of employee-empowerment and teamwork techniques [49] (which match the requirements of green human-resource management practices [2], aligned with environmental goals $[16,50])$. Due to people's commitment, after the implantation of LM, the ability to identify and eliminate sources of waste is extended to environmental issues without the need for other specific methodologies [51].

2. LM is a process of continuous improvement that focuses on the elimination of everything that does not add value to the product. When a process is improved, it becomes faster-as it involves less "waste" - [20] and, in addition, it can involve a more proficient use of materials, energy and natural resources [41]. Moreover, LM and environmental sustainability initiatives may focus on different objectives but share the same tools: while LM tries to reduce the consumption of materials to increase material efficiency, green manufacturing tries to reduce the consumption of materials in order to improve its impact on the environment, but both approaches may use the same techniques such as product re-design or recycling $[7,38,43]$. If this is the case, process improvement becomes a conjoint lean and green activity $[7,38,52]$. 
3. Equipment breakdown interrupts the production flow. For this reason, LM includes practices related to maintenance such as $5 \mathrm{~S}$ workplace organization method or total productive maintenance (TPM), which encourage operators to conduct inspections on the equipment, perform routine maintenance tasks and even improve the machines [15]. These lean practices help reduce wait time, improve machine performance and even ameliorate the environmental impact of the processes [14].

The implementation of green practices should lead to superior environmental performance [41], characterized by a reduction in waste generation, a reduction in the usage of raw materials and energy, and a reduction in environmental incidents. Likewise, beyond the scope of our empirical work, some studies indicate that, if green practices are promoted, aspects related to waste generation, production costs, and environmental incidents will be significantly improved [52,53]. Thus, in view of the above, we hypothesize the following:

Hypothesis 1a (H1a). The implementation of LM has a positive effect on the promotion of green practices.

Hypothesis $\mathbf{1 b} \mathbf{( H 1 b ) . ~ T h e ~ p r o m o t i o n ~ o f ~ g r e e n ~ p r a c t i c e s ~ h a s ~ a ~ p o s i t i v e ~ e f f e c t ~ o n ~ a ~ f i r m ' s ~ e n v i r o n m e n t a l ~ p e r f o r m a n c e . ~}$

\subsection{The Effect of Employee Involvement on the Relationship between Environmental Practices and Environmental Performance}

Cherrafi et al. [20] accept the contribution of LM to the environmental performance of a company, but they state that multiple barriers such as the lack of environmental awareness, resistance to change and lack of involvement may hinder the implementation and integration of lean and green initiatives and affect the environmental performance of the company. Zhang et al. [54] also presume that environmental commitment could improve companies' environmental performance.

Respect for people is one of the pillars of LM since its early origins at Toyota [27]. It holds that operators should not be regarded as mere machines but thinking workers. Therefore, LM pursues people's involvement in tasks such as problem-solving and process improvement [2] to achieve operational success [15]. In consequence, we could hypothesize that the same engagement is necessary to achieve environmental success. The seminal work by Rothenberg et al. [45] already considered worker involvement as a driver of environmental performance. Recently, Sartal et al. [2] empirically confirmed the positive relationship between "respect for people" and environmental performance. Taj [55], in their exploratory study on lean plants (although they were not in an advanced stage of the lean implementation) in innovative sectors in China, confirmed that $50 \%$ of the plants in his survey had implemented practices such as work teams, quality teams or problem solving. Accordingly, we posit the following hypotheses:

Hypothesis 2a (H2a). The implementation of $L M$ has a positive effect on employee involvement.

Hypothesis $\mathbf{2 b} \mathbf{( H 2 b )}$. Employee involvement has a positive effect on environmental performance.

However, it is difficult to change employee habits and foster employee involvement and thus, the implementation of LM may not guarantee the involvement of people. Employees may not be willing to cooperate [36] or to bear the pressure associated to pull production, which may be stressful [2,27]. Ulewicz and Kucęba [56] find that a lack of communication between management and employees may lead to lack of engagement and even to acts of sabotage. Moreover, especially in the initial stage of implementation of LM, employees may show a lukewarm attitude, and they may minimally cooperate in LM practices [19]. If operators are not predisposed, it is hard to improve processes, making it even more difficult to encourage green practices. Poorly implemented LM can lead to poor operational improvement [57] and, in a similar way, even if green practices are promoted, not much environmental improvement can be expected [17]. Based on the above, employee involvement may act as a moderator between the promotion of green practices and environmental performance. Thus, in view of the above, we hypothesize the following: 
Hypothesis 2c $\mathbf{( H 2 c ) . ~ E m p l o y e e ~ i n v o l v e m e n t ~ h a s ~ a ~ m o d e r a t i n g ~ e f f e c t ~ o n ~ t h e ~ r e l a t i o n s h i p ~ b e t w e e n ~ g r e e n ~ p r a c t i c e s ~}$ and environmental performance.

\subsection{The Influences of Pressure to Adopt Green Practices and ISO 14001 on the Relationship between LM and Green Practices}

Social, economic, and regulatory pressures incentivize companies to adopt green practices [8]. As people's environmental awareness has gradually grown, the pressure that a company may experience in the social, economic, and political spheres is considered the main factor influencing a company's environmental strategy [58]. Consequently, this pressure drives the implementation of green practices [59] in order to improve environmental performance. According to the principles of the institutional theory of the firm, Zhang et al. [54] empirically explored how regulatory pressure, pressure from external stakeholders who have interests in the organization and pressure to imitate the competitors (mainly in terms such as adopting an environmental management system) motivate green practices-namely those practices intended to reduce carbon dioxide emissions in Chinese iron and steel companies. Other studies $[1,9,60]$ evidenced a direct relationship between external pressure and sustainable practices.

However, our study also hypothesizes that LM promotes green practices, as claimed by other recent studies in different industries and countries $[15,34,59]$. Then, some relationships seem to exist between LM, environmental practices and the intensity of the pressure to "go green" and their combined effects should be studied together. Chen et al. [61] surmised that stakeholder pressure was a driver of the implementation of LM. However, their empirical analysis showed that pressure was only related to certain LM practices. Thus, while pressure to reduce the impact on the environment may be positively related to the promotion of green practices and the implementation of LM may also be positively related to such practices, the intensity of the pressure experienced by the company seems not to have any moderating effect on the relationship between LM and green practices. Since the intensity of the pressure perceived by the respondent is a subjective measure, we posit that LM influences the perception of such pressure because LM, beyond a set of practices, is a change in how people think and what they value [31]. Managers, imbued with a lean culture, feel compelled to take steps to implement green practices in response to stakeholder pressure. A related study [10] found that the relationship between pressure and green practices is totally mediated by environmentally oriented training programs. In consequence, it is necessary to raise people's environmental awareness and improve the skills required for green practices. Training is not specifically included in our model, but we assume that the implementation of LM develops people's skills and awareness. In consequence, the role of pressure on the relationship between LM and green practices deserves to be studied and this study hypothesizes the mediating effect of the pressure to "go green". We thus posit the following hypothesis:

Hypothesis 3 (H3). The pressure to "go green" experienced by companies has a mediating effect on the relationship between the implementation of $L M$ and the promotion of green practices.

Another way for firms to improve their environmental performance is by implementing an environmental management system (EMS) [62]. Most companies develop their EMSs based on the requirements set by the ISO 14001 standard. This standard asks certified companies to develop their environmental programs (where impacts on the environment are identified and responses are outlined) and, consequently, ISO 14001 can be considered to lead to the promotion of green practices. Kawai et al. [63] empirically verified that EMS implementation is positively associated with both green product innovation and green process innovation. Within the list of techniques used to improve processes, LM could be included. Rothenberg et al. [45] included ISO 14001 in their early lean and green framework. They found that LM leads to the adoption of ISO 14001 and increased environmental performance. This may suggest a mediating effect of EMS adoption on the relationship between LM and environmental performance. Habidin et al. [64] empirically verified this mediating effect but they 
also found that the relationship between ISO 14001 and performance was not significant $(p=0.051)$. Boiral and Henri [65] also found that there was no correlation between ISO 14001 and environmental performance, maybe because certification can be attributed to external pressures or marketing purposes while the company is not really committed to sustainability. In contrast, Castka and Prajogo [66] observed the structural relationship between ISO 14001 internalization (the requirements of the norm being truly put into practice) and environmental benefits.

Related studies [21,22] considered LM and ISO 14001 to be complementary and state that LM and ISO 14001 should be integrated to achieve synergies. Jabbour et al. [67] show that the requirements of ISO 14001 related to waste elimination and equipment maintenance highly overlap with the principles of LM and, consequently, both approaches can be integrated to create synergies [23,68]. Based on the above, lean implementation and ISO 14001 adoption should be studied at the same time.

However, compliance with ISO 14001 requires arduous processes and documentation [23], and the effort to implement both ISO 14001 and LM may be overwhelming. In consequence, lean companies that implement ISO 14001-based environmental management systems may find that the complicated processes of ISO 14001 become a barrier to LM implementation [68]. Based on the above, when firms implement LM and establish EMSs based on ISO 14001 to promote green practices, the adoption of ISO 14001 may run counter to company intentions in terms of LM and become a moderator. Thus, we develop and verify the following hypothesis:

Hypothesis 4 (H4). Adoption of the ISO 14001 standard has a moderating effect on the relationship between the implementation of LM and the application of green practices.

\subsection{Theoretical Framework}

According to the review of the literature and the above hypothesis development, this study develops the theoretical framework shown in Figure 1. In line with Figure 1, this study further tests the path relationships between the implementation of LM, promotion of green practices, environmental performance, pressure to reduce impact on the environment, ISO 14001 adoption, and employee involvement through statistical approaches. Through the verification of our theoretical framework and the clarification of the relationship between LM, green practices, and environmental performance, one can better understand the roles and influences of employee involvement, pressure to "go green", and ISO 14001 adoption within these processes.

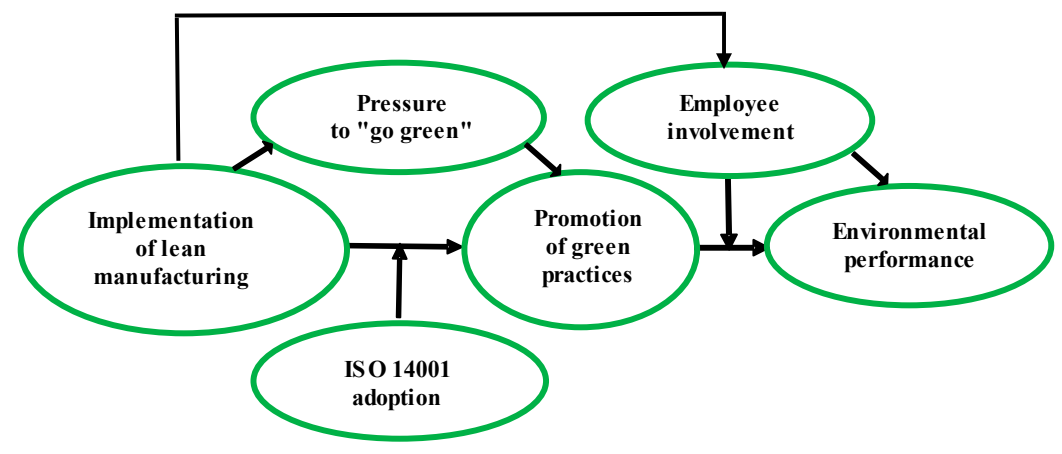

Figure 1. Theoretical framework.

\section{Materials and Methods}

\subsection{Questionnaire, Operationalization and Variables of the Constructs, Data Collection and Sample Profile}

To test the research hypotheses, this study utilizes survey-based empirical data from Chinese manufacturers. As part of a broader research project, a cross-sectional survey instrument was first designed (based on the theoretical framework and research hypotheses) and validated based on extant 
research. In line with the theoretical framework described in Figure 1, the questionnaire encompasses six constructs: (i) implementation of LM; (ii) promotion of green practices; (iii) environmental performance; (iv) pressure faced by companies; (v) ISO 14001 adoption and (vi) employee involvement. We reviewed related studies to define the operationalization of each construct and its related variables. These variables became the items or questions in the questionnaire (Table 1).

Table 1. Questionnaire content, operationalization, variables of each construct and citation source.

\begin{tabular}{|c|c|c|c|}
\hline Constructs & Variables & Operationalization & Sources \\
\hline \multicolumn{4}{|c|}{$\begin{array}{l}\text { 1. The "implementation of lean manufacturing }(\mathrm{LM}) \text { " construct measures the level of implementation of several shop floor practices. } \\
\text { Please measure your implementation level of LM based on the following items on a five-point Likert-type scale (from } 1=\text { not at all to } \\
5 \text { = fully implemented). }\end{array}$} \\
\hline $\begin{array}{l}\text { Implementation of lean } \\
\text { manufacturing }\end{array}$ & $\begin{array}{l}\text { I1. Just in Time/Pull production. } \\
\text { I2. Quick Setup. } \\
\text { I3. Total Productive Maintenance. } \\
\text { I4. Production Flow. } \\
\text { I5. Controlled Processes (they supply defect-free } \\
\text { units). }\end{array}$ & $\begin{array}{l}\text { Improving the production } \\
\text { activities and process through } \\
\text { waste elimination, pull } \\
\text { production and equipment } \\
\text { maintenance. }\end{array}$ & {$[18,69]$} \\
\hline \multicolumn{4}{|c|}{$\begin{array}{l}\text { 2. "Green practices" rates the adoption of such practices. } \\
\text { Please measure the level of adoption, in your company, of the following practices on a five-point Likert-type scale (from } 1=\text { not adopted } \\
\text { to } 5=\text { fully adopted). }\end{array}$} \\
\hline Green practices & $\begin{array}{l}\text { G1. Eco-design. } \\
\text { G2. Internal Environmental Management. } \\
\text { G3. Green Purchasing. } \\
\text { G4. Waste Management. }\end{array}$ & $\begin{array}{l}\text { Actions employed by an } \\
\text { organization with the aim of } \\
\text { protecting the environment } \\
\text { (e.g., to minimize negative } \\
\text { impacts). }\end{array}$ & [70] \\
\hline \multicolumn{4}{|c|}{$\begin{array}{l}\text { 3. "Environmental performance" captures the evolution of these indicators. } \\
\text { Please measure, according to your perception, your company's environmental performance on the following aspects }(1=\text { no } \\
\text { improvement } / 2=\text { poor } / 3=\text { fair } / 4=\operatorname{good} / 5=\text { very good }) \text {. }\end{array}$} \\
\hline $\begin{array}{l}\text { Environmental } \\
\text { performance }\end{array}$ & $\begin{array}{l}\text { P1. Pollution prevention. } \\
\text { P2. Usage of resource. } \\
\text { P3. Waste reduction: Reduce. } \\
\text { P4. Waste reduction: Reuse. } \\
\text { P5. Waste reduction: Recycle. } \\
\text { P6. Cooperation with customers including } \\
\text { environmental requirements. }\end{array}$ & $\begin{array}{l}\text { Environmental performance } \\
\text { means the effectiveness of } \\
\text { firms to coincide with social } \\
\text { expectations concerned with } \\
\text { the environment. }\end{array}$ & {$[52,53]$} \\
\hline \multicolumn{4}{|c|}{$\begin{array}{l}\text { 4. "Pressure to go green" gauges, according to the respondent's perception, the existence and importance of pressures to adopt } \\
\text { environmental-friendly practices. } \\
\text { (a) Please, specify your agreement with the following statements (Five-point Likert-type scale, from } 1=\text { strongly disagree to } \\
5=\text { strongly agree). } \\
\text { (b) Please, rate the importance for your company of each of these regulatory aspects (from } 1 \text { = not important to } 5=\text { very important). }\end{array}$} \\
\hline
\end{tabular}


Table 1. Cont.

\begin{tabular}{|c|c|c|c|}
\hline Constructs & Variables & Operationalization & Sources \\
\hline \multicolumn{4}{|c|}{$\begin{array}{l}\text { 5. "ISO } 14001 \text { adoption" is measured through the level of implementation of environmental management (EM procedures or standards. } \\
\text { For the following items, please measure your company's situation, with respect to ISO } 14001 \text { adoption. Use a five-point Likert-type scale: } \\
1=\text { not at all } / 2=\text { poor } 3=\text { fair } / 4=\text { good } / 5=\text { very good. }\end{array}$} \\
\hline ISO 14001 adoption & $\begin{array}{l}\text { IS1. Standards of product stewardship. } \\
\text { IS2. Standards of waste reduction (Reuse). } \\
\text { IS3. Standards of waste reduction (Recycle). } \\
\text { IS4. Standards of cooperation with customers } \\
\text { including environmental requirements (CC). }\end{array}$ & $\begin{array}{l}\text { Environmental Management } \\
\text { Systems help companies set } \\
\text { their environmental objectives } \\
\text { (including legal requirements } \\
\text { and non-regulated issues). }\end{array}$ & {$[17,73]$} \\
\hline \multicolumn{4}{|c|}{$\begin{array}{l}\text { 6. "Employee involvement" captures the respondent's perception of workers' involvement in the related processes. } \\
\text { Please, specify your agreement with the following statements (Five-point Likert-type scale, from } 1 \text { = strongly disagree to } \\
5=\text { strongly agree). }\end{array}$} \\
\hline Employee involvement & $\begin{array}{l}\text { EI1. Our employees intend to engage in } \\
\text { environmentally sustainable work activities. } \\
\text { EI2. Our employees think engaging in } \\
\text { environmentally sustainable work practices is } \\
\text { quite favorable. } \\
\text { EI3. Our employees know well the } \\
\text { environmental impact of waste management and } \\
\text { recycling at workplace. }\end{array}$ & $\begin{array}{l}\text { Techniques to engage } \\
\text { individuals (or groups) in } \\
\text { bottom-up communication } \\
\text { flow and decision-making } \\
\text { processes. }\end{array}$ & [74] \\
\hline
\end{tabular}

In autumn 2019, we collected empirical data using the questionnaire in Table 1. Questionnaires were sent to 306 manufacturing companies in China. A cluster non-probability sample was used since our population of interest is made up of companies with some experience in lean manufacturing-which is especially important since some authors have noticed an unsatisfactory implementation of LM in China [17] and thus it could shed some light on our research questions. China is an excellent target for our study because China accounts for over a quarter of the total world manufacturing value added-as is frequently said, China is the factory of the world - but this has caused important environmental problems such as pollution, greenhouse gas emissions and waste generation.

Since each sector has its own environmental issues, many scholars suggest a sector-based approach [54]. Respondents to our questionnaire are included in the same sectors used in related studies [44,61], which focused on industrial sectors depicted by the International Standard Industrial Classification (ISIC) divisions 25 to 30 (revision 4). However, our approach may limit the generalizability of our findings to other industries and countries. Furthermore, survey data can always be biased (see [2] for further discussion).

We received 220 valid responses (response rate $=71.9 \%$ ), which provided enough data for the evaluation of our research framework. In order to characterize the profile of the companies in the sample, we investigated three characteristics: enterprise size, product type, and age of implementation of LM. According to aggregated results, the characteristics of the respondents are shown in Table 2. They are either large mid-size firms or large companies (larger companies are most likely to implement the studied practices [6]) from the secondary sector, with incipient to young and, in some cases, mature lean systems.

Table 2. Sample profiles.

\begin{tabular}{cl}
\hline \multicolumn{1}{c}{ Characteristics } & Profiles \\
\hline & Up to $100=18.64 \%$ \\
& Between 101 and $300=39.55 \%$ \\
Enterprise size (Number of employees) & Between 301 and $500=12.73 \%$ \\
& Between 501 and $1000=16.36 \%$ \\
& Above $1000=12.73 \%$ \\
\hline
\end{tabular}


Table 2. Cont.

\begin{tabular}{cl}
\hline \multicolumn{1}{c}{ Characteristics } & \multicolumn{1}{c}{ Profiles } \\
\hline & Manufacture of Smart Grid and Intelligent Electrical Apparatus $=18.18 \%$ \\
& Manufacture of fabricated metal products, except machinery and equipment $=9.55 \%$ \\
& Manufacture of computer, electronic and optical products $=13.64 \%$ \\
& Manufacture of electrical equipment $=17.27 \%$ \\
Type of product (Industry description) & Manufacture of machinery and equipment not elsewhere classified $=16.82 \%$ \\
& Manufacture of motor vehicles, trailers and semi-trailers = 10.45\% \\
& Manufacture of other transport equipment $=7.73 \%$ \\
& Others $=6.36 \%$ \\
\hline \multirow{3}{*}{ Age of implementation of LM } & Under 1 year $=5 \%$ \\
& 1 year to 3 years $=31.36 \%$ \\
& 3 years to 5 years $=41.82 \%$ \\
& 5 years to 7 years $=16.36 \%$ \\
& Over 7 years $=5.45 \%$ \\
\hline &
\end{tabular}

\subsection{Data Analysis}

Partial least squares (PLS) analysis is a convenient method to study models that include complex cause-and-effect relationships between latent variables or constructs while including mediation and moderation effects [75]. PLS has been chosen as the right technique to statistically test our hypotheses because they involve path relationships and mediation and moderation effects among six constructs. In the PLS analysis, the significance of the research hypotheses about relationships between variables is tested by means of a bootstrapping procedure (5000 sub-samples-with replacement-are generated at random). The analysis process computes the path coefficients for each subsample and the $t$-value is also computed for every coefficient. Once we know whether every path coefficient is statistically significant or not, the result is applied to the evaluation of the research hypotheses. As the analysis tool, we used SmartPLS 3.0.

Before testing the research hypotheses with PLS, it is necessary to check the validity and reliability of the constructs [75]. For validity and reliability, factor loadings, composite reliability (CR), average variance extracted (AVE) and discriminant validity are the main measurement indices. All factor loadings should exceed 0.4 [76]. In addition, the CR and AVE should exceed 0.7 and 0.5 , respectively [75]. An AVE below 0.5, but above 0.36, can be accepted provided that the CR is above 0.7 [77]. In addition to the validity and reliability of the constructs, discriminant validity is also tested. Discriminant validity relates to whether each construct can be discriminated from the others and it evaluates the correlation among constructs. If the correlation value lies below 0.7 , every construct can be discriminated [77].

If the constructs satisfy the requirements of validity and reliability, PLS analysis can begin. The model's quality of fit should be measured within the process of PLS analysis and the standardized root-mean-square residual (SRMR) is used as the main index. The SRMR was intended to be used in covariance-based Structural Equations Modelling, but it has been extended to PLS. It is an approximate measure of the quality of fit of the model and it has been used by many researchers [78].

Before testing the hypotheses, we test the validity and reliability of the constructs. To do so, we evaluate the factor loadings, CR, AVE, and discriminant validity. The test results for the factor loadings, CR, and AVE are shown in Table 3, and the results for discriminant validity are shown in Table 4.

In Table 3, all factor loadings are above 0.4, and all CR values exceed 0.7 and thus they are satisfactory. CR is used to measure inter-item consistency. According to these values, all of the scales demonstrate acceptable results. We calculate the square roots of the AVE values, which measure the average variance shared between a construct and its measures [77]. The AVE values for green practices, environmental performance, ISO 14001 adoption, and employee involvement are higher than 0.5, satisfying the measurement requirements and the values of implementation of LM and pressure to "go green" are less than 0.5 but above 0.36 (still acceptable [77]). Table 4 shows the test results for discriminant validity. Since the correlation values between constructs are lower than 0.7 , the test results satisfy the requirements. Therefore, we can discriminate every construct. 
Table 3. Construct measures assessment: composite reliability and convergent validity.

\begin{tabular}{|c|c|c|c|c|}
\hline Constructs & Variables & Factor Loading & $\begin{array}{c}\text { Composite Reliability } \\
\text { CR }\end{array}$ & $\begin{array}{c}\text { Average Variance Extracted } \\
\text { AVE }\end{array}$ \\
\hline \multirow{5}{*}{$\begin{array}{l}\text { Implementation of lean } \\
\text { manufacturing }\end{array}$} & I1 & 0.722 & \multirow{5}{*}{0.797} & \multirow{5}{*}{0.441} \\
\hline & $\mathrm{I} 2$ & 0.696 & & \\
\hline & I3 & 0.590 & & \\
\hline & I4 & 0.639 & & \\
\hline & I5 & 0.672 & & \\
\hline \multirow{4}{*}{ Green practices } & G1 & 0.760 & \multirow{4}{*}{0.841} & \multirow{4}{*}{0.570} \\
\hline & G2 & 0.735 & & \\
\hline & G3 & 0.798 & & \\
\hline & G4 & 0.728 & & \\
\hline \multirow{6}{*}{$\begin{array}{l}\text { Environmental } \\
\text { performance }\end{array}$} & P1 & 0.772 & \multirow{6}{*}{0.876} & \multirow{6}{*}{0.542} \\
\hline & P2 & 0.759 & & \\
\hline & P3 & 0.675 & & \\
\hline & $\mathrm{P} 4$ & 0.760 & & \\
\hline & P5 & 0.753 & & \\
\hline & P6 & 0.694 & & \\
\hline \multirow{10}{*}{ Pressure to "go green" } & PR1 & 0.836 & \multirow{10}{*}{0.857} & \multirow{10}{*}{0.377} \\
\hline & PR2 & 0.655 & & \\
\hline & PR3 & 0.589 & & \\
\hline & PR4 & 0.514 & & \\
\hline & PR5 & 0.598 & & \\
\hline & PR6 & 0.418 & & \\
\hline & PR7 & 0.513 & & \\
\hline & PR8 & 0.710 & & \\
\hline & PR9 & 0.638 & & \\
\hline & PR10 & 0.826 & & \\
\hline \multirow{4}{*}{ ISO 14001 adoption } & IS1 & 0.669 & \multirow{4}{*}{0.813} & \multirow{4}{*}{0.524} \\
\hline & IS2 & 0.781 & & \\
\hline & IS3 & 0.670 & & \\
\hline & IS4 & 0.777 & & \\
\hline \multirow{3}{*}{ Employee involvement } & EI1 & 0.692 & \multirow{3}{*}{0.765} & \multirow{3}{*}{0.521} \\
\hline & EI2 & 0.745 & & \\
\hline & EI3 & 0.726 & & \\
\hline
\end{tabular}

Table 4. Discriminant validity (Correlation).

\begin{tabular}{cccccccc}
\hline & Mean & SD & LM & $\begin{array}{c}\text { Green } \\
\text { Practi. }\end{array}$ & Performance & Pressure & ISO 14001 \\
\hline Implementation of LM & 3.911 & 0.625 & - & & & & \\
$\quad$ Green practices & 4.001 & 0.684 & 0.443 & - & & & \\
Environmental performance & 3.923 & 0.709 & 0.327 & 0.698 & - & - & 0.437 \\
$\quad$ Pressure "to go green" & 4.058 & 0.524 & 0.457 & 0.352 & 0.445 & 0.323 & 0.437 \\
$\quad$ ISO 14001 adoption & 4.005 & 0.641 & 0.342 & 0.221 & 0.443 & 0.468 \\
Employee involvement & 4.106 & 0.526 & 0.372 & 0.278 & 0.312 & 0.43 \\
\hline
\end{tabular}

\section{Results}

The PLS analysis results are shown in Table 5. This table shows the path coefficients and the explanation of the construct variances $\left(R^{2}\right)$. In terms of the construct variances, we find that each of the endogenous variables is adequate, explaining $22.5 \%$ of the variance for green practices, $52.3 \%$ for environmental performance, $20.9 \%$ for pressure to "go green", and $14.2 \%$ for employee involvement. Regarding the test results of the hypotheses, the path coefficient for the relationship between the implementation of LM and the adoption of green practices is $0.347(p<0.01)$; thus, we can conclude that there is a positive correlation between both variables, supporting hypothesis H1a. For the relationship between the adoption of green practices and the environmental performance, the path coefficient is $0.640(p<0.01)$; thus, green practices have a positive effect on environmental performance, which supports hypothesis $\mathrm{H} 1 \mathrm{~b}$. In addition to testing whether LM has positive effects on green practices, this study also examines the relationships between implementation of LM, employee involvement, and environmental performance. The path coefficient for the relationship between 
implementation of LM and employee involvement is $0.377(p<0.01)$ and the path coefficient for the relationship between employee involvement and environmental performance is $0.166(p<0.01)$. Therefore, hypotheses $\mathrm{H} 2 \mathrm{a}$ and $\mathrm{H} 2 \mathrm{~b}$ are supported. Furthermore, hypothesis $\mathrm{H} 2 \mathrm{c}$ is supported because the path coefficient is $0.137(p<0.05)$, illustrating a moderating effect of employee involvement on the relationship between the adoption of green practices and environmental performance. The path coefficient for the relationship between the implementation of LM and the pressure to "go green" is $0.457(p<0.01)$ and the path coefficient for the relationship between pressure and environmental practices is $0.179(p<0.05)$. These findings suggest that pressure to "go green" has a mediating effect on the relationship between the implementation of $\mathrm{LM}$ and green practices, which supports hypothesis $\mathrm{H} 3$. Finally, regarding the moderating effect of ISO 14001 adoption, the path coefficient is $-0.001(p>0.05)$ indicating that hypothesis $\mathrm{H} 4$ is unsupported. In terms of measuring the model fit, the SRMR is the primary index used. According to the test, the SRMR is 0.071 , which is lower than 0.08 , and the model fit can be accepted.

Table 5. Partial least squares (PLS) structural model results.

\begin{tabular}{|c|c|c|c|c|}
\hline & Hypotheses & $\begin{array}{c}\text { Standardized } \\
\text { Coefficient }\end{array}$ & t-Value & Results \\
\hline H1a & Implementation of LM -> Green practices & 0.347 & $3.736 * *$ & Supported \\
\hline $\mathrm{H} 1 \mathrm{~b}$ & Green practices -> Environmental performance & 0.640 & $11.862 * *$ & Supported \\
\hline $\mathrm{H} 2 \mathrm{a}$ & LM -> Employee involvement & 0.377 & $6.563 * *$ & Supported \\
\hline $\mathrm{H} 2 \mathrm{~b}$ & Employee involvement -> Environmental performance & 0.166 & $2.925^{* *}$ & Supported \\
\hline $\mathrm{H} 2 \mathrm{c}$ & Moderating effect of employee involvement & 0.137 & $2.423 *$ & Supported \\
\hline \multirow{2}{*}{ H3 } & Implementation of LM -> Pressure to "go green" & 0.457 & $6.766 * *$ & \\
\hline & Pressure to "go green" -> Green practices & 0.179 & $2.043 *$ & Supported \\
\hline $\mathrm{H} 4$ & Moderating effect of ISO 14001 adoption & -0.001 & 0.0160 & Unsupported \\
\hline \multicolumn{5}{|c|}{ Variance explained in the endogenous variables } \\
\hline & Green practices & $R^{2}=0.225$ & & \\
\hline & Environmental performance & $R^{2}=0.523$ & & \\
\hline & Pressure to "go green" & $R^{2}=0.209$ & & \\
\hline & Employee involvement & $R^{2}=0.142$ & & \\
\hline & Model fit & & & \\
\hline & Standardized root-mean-square residual SRMR & 0.071 & & \\
\hline
\end{tabular}

${ }^{* *} p<0.01,{ }^{*} p<0.05$.

\section{Discussion}

Based on the test results, this section provides further discussion. First, according to our test results, the implementation of LM has a positive effect on the application of green practices, thus allowing the achievement of a high environmental performance. Test results are in consonance with successful cases in the literature that show that "lean is green" and go one step further because they show that there is a correlation between the implementation of LM and different green practices such as eco-design and green purchasing.

Second, concerning the issue of employee involvement, even though LM fosters employee involvement, employees may neither be willing to cooperate nor show a strong commitment [56]. These operators may not put forth their best efforts in green practices [57] and this may affect environmental performance. Our research results proved that, in our sample, LM is able to encourage employee involvement and this commitment is important to ensure that green practices lead to an outstanding environmental performance. According to our test results, employee involvement has a moderating effect and affects the relationship between green practices and environmental performance. However, why is that so? This problem has to do with the psychology of workers. When employees experience a work atmosphere that persuades them to get involved in problem-solving, but they do not get imbued with a lean culture, their attitude towards work becomes passive $[79,80]$. Even if workers participate in green practices, their passive attitude may lead to poor results of such practices and poor environmental performance. Therefore, employee involvement becomes a moderator that affects the relationship between green practices and environmental performance. 
Third, according to the test results related to hypothesis H3, pressure to "go green" has a mediating effect and affects the relationship between the implementation of LM and the promotion of green practices. Chen et al. [61] empirically found a correlation between some lean practices and stakeholder pressure to "green" the company. Considering that this paper has shown that the hypothesis of a relationship between the implementation of LM and green practices is supported, this study sought to determine whether pressure may have a mediating effect on the relationship between the implementation of LM and green practices. LM has the ability to change how people behave and think. This is what we call "lean culture", a culture of continuous improvement and fight against all forms of waste [81]. These values help create environmental awareness and make people pay attention to the demands of more sustainable manufacturing [81,82]. This explains why lean companies implement green practices in response to stakeholder pressure, whether using specific LM tools $[14,61]$ or not. Our results agree with those achieved by González-Benito and González-Benito [82], connecting LM with environmental practices through two paths, both depending on lean culture, with one way specially influenced by environmental pressure of stakeholders, as perceived by the company management.

Finally, regarding the moderating effect of adopting ISO 14001, this hypothesis was unsupported, suggesting that ISO 14001 adoption does not exert a moderating effect on the relationship between the implementation of LM and green practices. Nonetheless, if ISO 14001 adoption is combined with implementation of LM at the same time, despite the complexity of the process, both approaches will contribute, in a synergistic way, to the promotion of green practices. To verify this conjecture, although this study does not establish a hypothesis to test whether ISO 14001 adoption has a positive effect on the implementation of LM, we eliminated the moderating effect of ISO 14001 from our model and built a path between the ISO 14001 construct and the LM construct (Figure 2). When the model was tested, this new path coefficient was $0.341(p<0.01)$. The path coefficient between LM and green practices was $0.347(p<0.01)$ in the original model. However, when the relationship between LM and ISO 14001 is included in the model, the path coefficient between LM and green practices increases to $0.354(p<0.01)$ while all other path coefficients remain practically constant. According to the results of this test, LM and the adoption of an ISO 14001-based EMS can be integrated and be a greater driving force promoting green practices due to the congruence between their principles and requirements. This conclusion agrees with the studies [21,22] that suggest an integrative effect between LM and ISO 14001. In consequence our research provides empirical support to those studies.

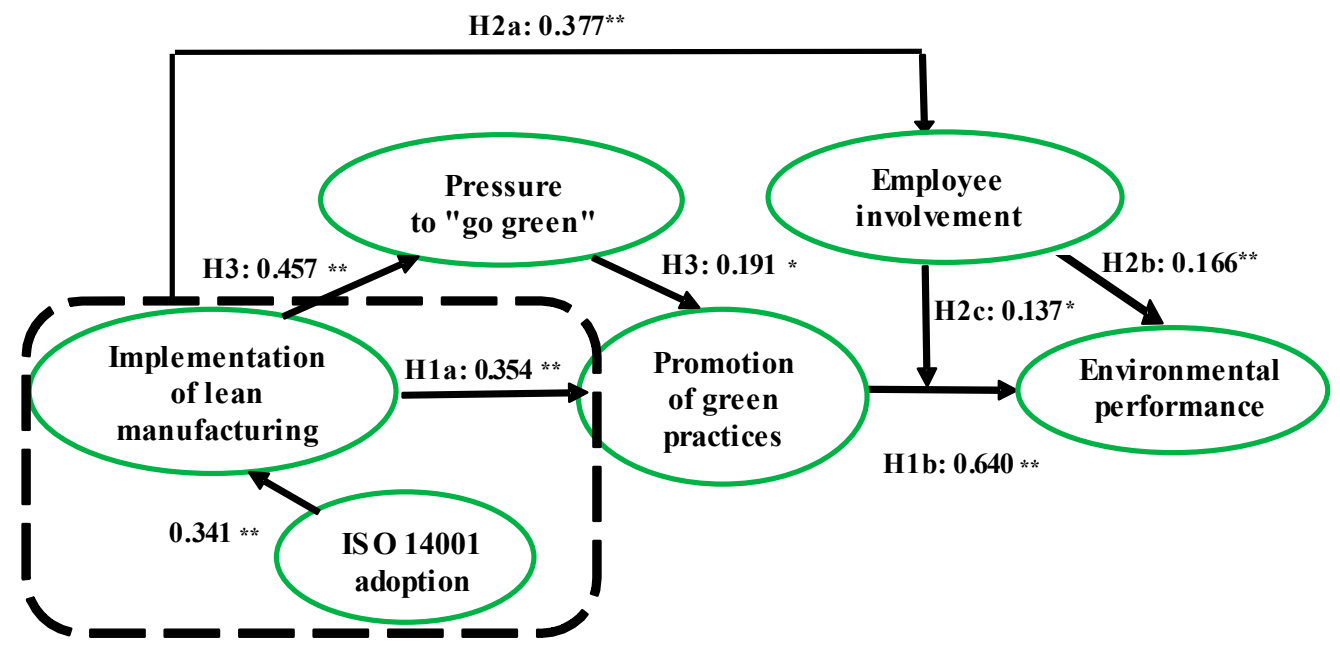

Model fit: $\mathrm{SRMR}=\mathbf{0 . 0 7 2} \quad * * p<0.01, * p<0.05$

Figure 2. Test results of integration between ISO 14001 adoption and implementation of lean manufacturing (LM). 
Based on these findings, this study provides valuable research results. However, since our work is based on companies from a single country, we might wonder whether national culture would prevent our study from being transposed to other regions of the globe. For example, companies may claim that they cannot implement LM because they are not Japanese. Sartal et al. [33] verified that organizational culture totally mediates the relation between lean tools and operational performance. This means that, although the values of a specific nation or company are not those that inspired Toyota, a lean implementation may be successful as long as the company lets lean practices prompt the necessary cultural changes, based on values which are compatible with LM [20]. Nevertheless, this cultural change is crucial to ensure long-term success. In this regard, Bortolotti et al. [83] confirm the relevance of practices such as group problem solving and multiskilled operators. Based on the above findings, when manufacturers from other countries try to improve their environmental performance through LM, they will likely encounter the same questions that our research poses and will have to promote the necessary cultural change.

\section{Conclusions and Implications}

Because companies are likely to face new challenges in terms of management of their processes [6] in order to advance towards sustainable manufacturing, this study sheds light on the role of LM in environmental sustainability. It also explores other determinants such as stakeholder pressure, ISO 14001 adoption and employee empowerment. The literature suggests that LM may have an impact on environmental performance. Our results show that this relationship is not straightforward. Environmental performance is based on environmental practices, because LM is not "green" per se. Employee involvement-which emerges from LM-acts as a moderator and it may either enhance or damage the relationship between green practices and environmental performance. The relationship between LM and green practices is two-fold. On one hand it is based on the development of a lean culture. On the other hand, it is mediated by the perceived pressure to reduce impact on the environment, which is attributed to the environmental awareness that stems from LM. Finally, we proved that ISO 14001 adoption has no moderating effect on the relationship between LM and green practices but, more importantly, this study proved that green practices are markedly promoted if a company implements LM and an EMS in an integrated manner.

This study provides valuable managerial implications that are both academic and practical. Regarding the academic implications, this study developed a theoretical framework based on gaps and conflicts in the extant literature. We developed our research questions from the perspective of LM, taking into account the human side of LM, and its relationship with ISO 14001 and found that attitude is paramount to improve environmental sustainability. This opens new questions for research: at a macro level, a more holistic view can be adopted, because in extant research only partial relations have been studied and a more complex model should be analyzed. For example, lean culture should be a considered as a specific construct. At a micro level, an analysis of the relationship between different lean tools and environmental practices should be undertaken, in order to clarify their particular usefulness. Researchers should rethink the role of employee involvement and pressure along with the adoption of ISO 14001. Many studies report that employee involvement is a consequence of LM, but they ignore the nature of people, which may negatively affect green performance. This viewpoint should be further studied. In addition, some researchers have indicated that pressure to "go green" may drive manufacturers to implement LM for environmental purposes but, according to our results, pressure also plays a mediating role and its existence ensures the maintenance of green practices. Finally, the synergy between ISO 14001 and LM, outlined in our paper, should be further studied.

Regarding the practical implications, we proved the LM drives employee involvement to ensure the effect of LM on environmental performance. However, our test results also show that, as a moderator, involvement may enhance or damage the relationship between green practices and environmental performance. For this reason, manufacturers need to explore how to encourage and enhance employee engagement through a positive and efficient approach, such as training employees 
or developing team building [84]. LM contributes to shape employee behavior and attitudes. Thus, managers must be careful that LM develops a true lean culture. Furthermore, the connection between LM and environmental practices must be reinforced with training and environmental awareness. The mediating effect of pressure to "go green" can be used by manufacturers to maintain the effect of LM on green practices in a similar way as pressure is used in LM to achieve pull production. Moreover, since the pressure that one may experience is related to LM, we have one more reason to develop a lean culture. Our research also discussed why ISO 14001 adoption is important. This result will guide manufacturers to rethink mechanisms to combine LM and ISO 14001 in order to realize high environmental performance and further environmental sustainability.

Finally, the results of our study have implications for industrial policies aimed to accelerate a transformation towards a green sustainable society while enabling productivity enhancements [85]. Governments should support the environmental benefits of LM. As an example, the Environmental Protection agency (EPA) has been disseminating the lean and green paradigm for years (see for example [86]) to help companies reduce their environmental footprint.

Author Contributions: Conceptualization and research design, P.-K.C., I.L.-B., J.F.-S. and P.R.-d.-A.-L.; data acquisition and statistical analysis, P.-K.C.; original draft, P.-K.C.; refined and edited by P.-K.C., I.L.-B., J.F.-S. and P.R.-d.-A.-L. All authors have read and agreed to the published version of the manuscript.

Funding: This study was supported by National Natural Science Foundation of China (NSFC, Grant no. 71872131) and STU Scientific Research Initiation Grant (SRIG, Grant no. 20007).

Acknowledgments: Authors want to express their gratitude to those who took part in the survey.

Conflicts of Interest: The authors declare no conflict of interest.

\section{References}

1. Dubey, R.; Gunasekaran, A.; Ali, S.S. Exploring the relationship between leadership, operational practices, institutional pressures and environmental performance: A framework for green supply chain. Int. J. Prod. Econ. 2015, 160, 120-132. [CrossRef]

2. Sartal, A.; Martinez-Senra, A.I.; Cruz-Machado, V. Are all lean principles equally eco-friendly? A panel data study. J. Clean. Prod. 2018, 177, 362-370. [CrossRef]

3. Sartal, A.; Bellas, R.; Mejias, A.M.; Garcia-Collado, A. The sustainable manufacturing concept, evolution and opportunities within Industry 4.0: A literature review. Adv. Mech. Eng. 2020, 12, 12. [CrossRef]

4. Moldavska, A.; Welo, T. The concept of sustainable manufacturing and its definitions: A content-analysis based literature review. J. Clean. Prod. 2017, 166, 744-755. [CrossRef]

5. Bonvoisin, J.; Stark, R.; Seliger, G. Field of research in sustainable manufacturing. In Sustainable Oroduction, Life Cycle Engineering and Management; Jantzen, P., Ed.; Springer Nature: Berlin, German, 2017; pp. 3-20.

6. Cherrafi, A.; Garza-Reyes, J.A.; Kumar, V.; Mishra, N.; Ghobadian, A.; Elfezazi, S. Lean, green practices and process innovation: A model for green supply chain performance. Int. J. Prod. Econ. 2018, 206, 79-92. [CrossRef]

7. Sartal, A.; Rodríguez, M.; Vázquez, X.H. From efficiency-driven to low-carbon operations management: Implications for labor productivity. J. Oper. Manag. 2020, 66, 310-325. [CrossRef]

8. Kim, M.; Chai, S. Implementing environmental practices for accomplishing sustainable green supply chain management. Sustainability 2017, 9, 1192. [CrossRef]

9. Baah, C.; Jin, Z.; Tang, L. Organizational and regulatory stakeholder pressures friends or foes to green logistics practices and financial performance: Investigating corporate reputation as a missing link. J. Clean. Prod. 2020, 247, 119-125. [CrossRef]

10. Sarkis, J.; Gonzalez-Torre, P.; Adenso-Diaz, B. Stakeholder pressure and the adoption of environmental practices: The mediating effect of training. J. Oper. Manag. 2010, 28, 163-176. [CrossRef]

11. Zhu, Q.; Sarkis, J. An inter-sectoral comparison of green supply chain management in China: Drivers and practices. J. Clean. Prod. 2006, 14, 472-486. [CrossRef]

12. Merli, R.; Preziosi, M.; Ippolito, C. Promoting sustainability through EMS application: A survey examining the critical factors about EMAS registration in Italian organizations. Sustainability 2016, 8, 197. [CrossRef] 
13. Jabbour, C.J.C.; De Sousa Jabbour, A.B.L.; Govindan, K.; De Freitas, T.P.; Soubihia, D.F.; Kannan, D.; Latan, H. Barriers to the adoption of green operational practices at Brazilian companies: Effects on green and operational performance. Int. J. Prod. Res. 2016, 54, 3042-3058. [CrossRef]

14. Chiarini, A. Sustainable manufacturing-greening processes using specific Lean Production tools: An empirical observation from European motorcycle component manufacturers. J. Clean. Prod. 2014, 85, 226-233. [CrossRef]

15. Kalyar, M.N.; Shafique, I.; Abid, A. Role of lean manufacturing and environmental management practices in eliciting environmental and financial performance: The contingent effect of institutional pressures. Environ. Sci. Pollut. Res. 2019, 26, 24967-24978. [CrossRef]

16. Yu, W.; Chavez, R.; Feng, M.; Wong, C.Y.; Fynes, B. Green human resource management and environmental cooperation: An ability-motivation-opportunity and contingency perspective. Int. J. Prod. Econ. 2020, 219, 224-235. [CrossRef]

17. Fu, X.; Guo, M.; Zhanwen, N. Applying the green embedded lean production model in developing countries: A case study of China. Environ. Dev. 2017, 24, 22-35. [CrossRef]

18. Garza-Reyes, J.A.; Kumar, V.; Chaikittisilp, S.; Tan, K.H. The effect of lean methods and tools on the environmental performance of manufacturing organisations. Int. J. Prod. Econ. 2018, 200, 170-180. [CrossRef]

19. Keyser, R.S.; Sawhney, R.S.; Marella, L. A management framework for understanding change in a lean environment. Tékhne 2016, 56, 31-44. [CrossRef]

20. Cherrafi, A.; Elfezazi, S.; Garza-Reyes, J.A.; Benhida, K.; Mokhlis, A. Barriers in Green Lean implementation: A combined systematic literature review and interpretive structural modelling approach. Prod. Plan. Control. 2017, 28, 829-842. [CrossRef]

21. Kurdve, M.; Zackrisson, M.; Wiktorsson, M.; Harlin, U. Lean and green integration into production system models-experiences from Swedish industry. J. Clean. Prod. 2014, 85, 180-190. [CrossRef]

22. Puvanasvaran, P.; Tian, R.K.S.; Suresh, A.; Vasu, L. Lean environmental management integration system for sustainability of ISO 14001: 2004 standard implementation. J. Ind. Eng. Manag. 2014, 7, 1124-1144. [CrossRef]

23. Schmidt, J.S.; Osebold, R. Environmental management systems as a driver for sustainability: State of implementation, benefits and barriers in German construction companies. J. Civ. Eng. Manag. 2017, 23, 150-162. [CrossRef]

24. Sugimori, Y.; Kusunoki, K.; Cho, F.; Uchikawa, S. Toyota production system and kanban system materialization of just-in-time and respect-for-human system. Int. J. Prod. Res. 1977, 15, 553-564. [CrossRef]

25. Krafcik, J.F. Triumph of the lean production system. MIT Sloan Manag. Rev. 1988, 30, 41-52.

26. Womack, J.P.; Jones, D.T.; Roos, D. The Machine That Changed the World; Rawson Associates: New York, NY, USA, 1990.

27. Ohno, T. Toyota Production System: Beyond Large-Scale Production; Productivity Press: Portland, OR, USA, 1988.

28. Franchetti, M.; Bedal, K.; Ulloa, J.; Grodek, S. Lean and green: Industrial engineering methods are natural stepping stones to green engineering. Ind. Eng. 2009, 41, 24-30.

29. Pettersen, J. Defining lean production: Some conceptual and practical issues. TQM J. 2009, 21, 127-142. [CrossRef]

30. Cassell, C.; Worley, J.M.; Doolen, T.L. The role of communication and management support in a lean manufacturing implementation. Manag. Decis. 2016, 44, 228-245.

31. Bhamu, J.; Singh Sangwan, K. Lean manufacturing: Literature review and research issues. Int. J. Oper. Prod. Manag. 2014, 34, 876-940. [CrossRef]

32. Netland, T.; Powell, D. The Routledge Companion to Lean Management; Routledge: New York, NY, USA, 2016.

33. Sartal, A.; Vázquez, X.H.; Lozano-Lozano, L.M. Organizational tools and cultural change in the success of lean transformations: Delving into sequence and rhythm. IEEE Trans. Eng. Manag. 2020, 1-13. [CrossRef]

34. Niemann, W.; Kotzé, T.; Josi, B. The 'lean and green' paradigm: Drivers, barriers and practices in the South African airline services industry. J. Contemp. Manag. 2018, 15, 605-635.

35. Maxwell, J.; Briscoe, F.; Schenk, B.; Rothenberg, S. Case study: Honda of America Manufacturing, Inc.: Can lean production practices increase environmental performance? Environ. Qual. Manag. 1998, 8, $53-61$. [CrossRef]

36. Florida, R. Lean and green: The move to environmentally conscious manufacturing. Calif. Manag. Rev. 1996, 39, 80-105. [CrossRef] 
37. Henao, R.; Sarache, W.; Gómez, I. Lean manufacturing and sustainable performance: Trends and future challenges. J. Clean. Prod. 2019, 208, 99-116. [CrossRef]

38. Abualfaraa, W.; Salonitis, K.; Al-Ashaab, A.; Ala'raj, M. Lean-Green Manufacturing Practices and Their Link with Sustainability: A Critical Review. Sustainability 2020, 12, 981. [CrossRef]

39. Khodeir, L.M.; Othman, R. Examining the interaction between lean and sustainability principles in the management process of AEC industry. Ain Shams Eng. J. 2018, 9, 1627-1634. [CrossRef]

40. Farias, L.M.S.; Santos, L.C.; Gohr, C.F.; Oliveira, L.C.; Amorim, M.H.D.S. Criteria and practices for lean and green performance assessment: Systematic review and conceptual framework. J. Clean. Prod. 2019, 218, 746-762. [CrossRef]

41. Hartini, S.; Ciptomulyono, U. The relationship between lean and sustainable manufacturing on performance: Literature review. Procedia Manuf. 2015, 4, 38-45. [CrossRef]

42. Luján-Blanco, I.; Fortuny-Santos, J. Towards a green company through lean manufacturing. Review and state-of-the-art. Dyna Manag. 2016, 4, 1-11.

43. Dües, C.M.; Tan, K.H.; Lim, M. Green as the new lean: How to use lean practices as a catalyst to greening your supply chain. J. Clean. Prod. 2013, 40, 93-100. [CrossRef]

44. Yang, M.G.M.; Hong, P.; Modi, S.B. Impact of lean manufacturing and environmental management on business performance: An empirical study of manufacturing firms. Int. J. Prod. Econ. 2011, 129, 251-261. [CrossRef]

45. Rothenberg, S.; Pil, F.K.; Maxwell, J. Lean, green, and the quest for superior environmental performance. Prod. Oper. Manag. 2001, 10, 228-243. [CrossRef]

46. Dieste, M.; Panizzolo, R.; Garza-Reyes, J.A.; Anosike, A. The relationship between lean and environmental performance: Practices and measures. J. Clean. Prod. 2019, 224, 120-131. [CrossRef]

47. Caldera, H.T.S.; Desha, C.; Dawes, L. Exploring the role of lean thinking in sustainable business practice: A systematic literature review. J. Clean. Prod. 2017, 167, 1546-1565. [CrossRef]

48. Babur, F.; Cevikcan, E.; Durmusoglu, M.B. Axiomatic Design for Lean-oriented Occupational Health and Safety systems: An application in shipbuilding industry. Comput. Ind. Eng. 2016, 100, 88-109. [CrossRef]

49. Olivella, J.; Cuatrecasas, L.; Gavilan, N. Work organization practices for lean production. J. Manuf. Tech. Manag. 2008, 19, 798-811. [CrossRef]

50. Jabbour, C.J.C.; De Sousa Jabbour, A.B.L. Green human resource management and green supply chain management: Linking two emerging agendas. J. Clean. Prod. 2016, 112, 1824-1833. [CrossRef]

51. Shetlar, C.; Eckhardt, J.; Messmer, B.; Adams, J.; Rogers, B. A lean laboratory 'goes green'. MLO Med. Lab. Obs. 2010, 42, 26-28.

52. Verrier, B.; Rose, B.; Caillaud, E. Lean and Green strategy: The Lean and Green House and maturity deployment model. J. Clean. Prod. 2016, 116, 150-156. [CrossRef]

53. Ng, R.; Low, J.S.C.; Song, B. Integrating and implementing Lean and Green practices based on proposition of Carbon-Value Efficiency metric. J. Clean. Prod. 2015, 95, 242-255. [CrossRef]

54. Zhang, B.; Wang, Z.; Yin, J.; Su, L. $\mathrm{CO}_{2}$ emission reduction within Chinese iron \& steel industry: Practices, determinants and performance. J. Clean. Prod. 2012, 33, 167-178.

55. Taj, S. Applying lean assessment tools in Chinese hi-tech industries. Manag. Decis. 2005, 43, $628-643$. [CrossRef]

56. Ulewicz, R.; Kuceba, R. Identification of problems of implementation of Lean concept in the SME sector. Eng. Manag. Prod. Serv. 2016, 8, 19-25. [CrossRef]

57. Østbø, P.; Wetherill, M.; Cattermole, R. Leading Beyond Lean; Palgrave Macmillan: London, UK, 2016.

58. Lee, J.W.; Kim, Y.M.; Kim, Y.E. Antecedents of adopting corporate environmental responsibility and green practices. J. Bus. Ethics 2018, 148, 397-409. [CrossRef]

59. Muñoz-Villamizar, A.; Santos, J.; Viles, E.; Ormazábal, M. Manufacturing and environmental practices in the Spanish context. J. Clean. Prod. 2018, 178, 268-275. [CrossRef]

60. Muhammad Auwal, A.; Mohamed, Z.; Nasir Shamsudin, M.; Sharifuddin, J.; Ali, F. External pressure influence on entrepreneurship performance of SMEs: A case study of Malaysian herbal industry. J. Small Bus. Entrep. 2020, 32, 149-171. [CrossRef]

61. Chen, P.K.; Fortuny-Santos, J.; Lujan, I.; Ruiz-de-Arbulo-López, P. Sustainable manufacturing: Exploring antecedents and influence of Total Productive Maintenance and lean manufacturing. Adv. Mech. Eng. 2019, 11, 1687814019889736. [CrossRef] 
62. Delmas, M. Stakeholders and competitive advantage: The case of ISO 14001. Prod. Oper. Manag. 2001, 10, 343-358. [CrossRef]

63. Kawai, N.; Strange, R.; Zucchella, A. Stakeholder pressures, EMS implementation, and green innovation in MNC overseas subsidiaries. Int. Bus. Rev. 2018, 27, 933-946. [CrossRef]

64. Habidin, N.F.; Hibadullah, S.N.; Fuzi, N.M.; Salleh, M.I.; Md Latip, N.A. Lean manufacturing practices, ISO 14001, and environmental performance in Malaysian automotive suppliers. Int. J. Manag. Sci. Eng. Manag. 2018, 13, 45-53. [CrossRef]

65. Boiral, O.; Henri, J.F. Modelling the impact of ISO 14001 on environmental performance: A comparative approach. J. Environ. Manag. 2012, 99, 84-97. [CrossRef]

66. Castka, P.; Prajogo, D. The effect of pressure from secondary stakeholders on the internalization of ISO 14001. J. Clean. Prod. 2013, 47, 245-252. [CrossRef]

67. Jabbour, C.J.C.; De Sousa Jabbour, A.B.L.; Govindan, K.; Teixeira, A.A.; De Souza Freitas, W.R. Environmental management and operational performance in automotive companies in Brazil: The role of human resource management and lean manufacturing. J. Clean. Prod. 2013, 47, 129-140. [CrossRef]

68. Puvanasvaran, A.L.; Perumal, A.; Tian, R.K.S.; Vasu, S.A.; Muhamad, M.R. Integration model of ISO 14001 with lean principles. Am. J. Appl. Sci. 2012, 9, 1974-1978.

69. Panizzolo, R.; Garengo, P.; Sharma, M.K.; Gore, A. Lean manufacturing in developing countries: Evidence from Indian SMEs. Prod. Plan. Control 2012, 23, 769-788. [CrossRef]

70. Guo, L.; Xu, Y.; Liu, G.; Wang, T. Understanding Firm Performance on Green Sustainable Practices through Managers' Ascribed Responsibility and Waste Management: Green Self-Efficacy as Moderator. Sustainability 2019, 11, 4976. [CrossRef]

71. Dai, J.; Chan, H.K.; Yee, R.W.Y. Examining moderating effect of organizational culture on the relationship between market pressure and corporate environmental strategy. Ind. Mark. Manag. 2018, 74, 227-236. [CrossRef]

72. Esfahbodi, A.; Zhang, Y.; Watson, G.; Zhang, T. Governance pressures and performance outcomes of sustainable supply chain management-An empirical analysis of UK manufacturing industry. J. Clean. Prod. 2017, 155, 66-78. [CrossRef]

73. Da Fonseca, L.M.C.M. ISO 14001: 2015: An improved tool for sustainability. J. Ind. Eng. Manag. 2015, 8, 37-50.

74. Ceptureanu, E.G.; Ceptureanu, S.I.; Bologa, R.; Bologa, R. Impact of Competitive Capabilities on Sustainable Manufacturing Applications in Romanian SMEs from the Textile Industry. Sustainability 2018, 10, 942. [CrossRef]

75. Hair, J.F., Jr.; Hult, G.T.M.; Ringle, C.; Sarstedt, M. A Primer on Partial Least Squares Structural Equation Modeling (PLS-SEM); Sage Publications: Thousand Oaks, CA, USA, 2016.

76. Hasan, B.; Ali, J. An empirical examination of factors affecting group effectiveness in information systems projects. Decis. Sci. J. Innov. Educ. 2007, 5, 229-243. [CrossRef]

77. Fornell, C.; Larcker, D.F. Evaluating structural equation models with unobservable variables and measurement error. J. Mark. Res. 1981, 18, 39-50. [CrossRef]

78. Shi, Y.W.; Chen, P.K.; Ye, Y. Factors for improving and moderating a successful supply chain. J. Bus. Econ. Manag. 2019, 20, 20-42. [CrossRef]

79. Neff, W.S. Work and Human Behavior; Routledge: London, UK, 2017.

80. Wu, T.J.; Wu, Y.J. Innovative work behaviors, employee engagement, and surface acting. Manag. Decis. 2019, 57, 3200-3216. [CrossRef]

81. Alves, J.R.X.; Alves, J.M. Production management model integrating the principles of lean manufacturing and sustainability supported by the cultural transformation of a company. Int. J. Prod. Res. 2015, 53, 5320-5333. [CrossRef]

82. González-Benito, J.; González-Benito, O. The role of stakeholder pressure and managerial values in the implementation of environmental logistics practices. Int. J. Prod. Res. 2006, 44, 1353-1373. [CrossRef]

83. Bortolotti, T.; Boscari, S.; Danese, P. Successful lean implementation: Organizational culture and soft lean practices. Int. J. Prod. Econ. 2015, 160, 182-201. [CrossRef]

84. Chiarini, A.; Brunetti, F. What really matters for a successful implementation of Lean production? A multiple linear regression model based on European manufacturing companies. Prod. Plan. Control 2019, 30, 1091-1101. [CrossRef] 
85. Altenburg, T.; Rodrik, D. 2017 Green industrial policy: Accelerating structural change towards wealthy green economies. In Green Industrial Policy. Concept, Policies, Country Experiences; Altenburg, T., Assmann, C., Eds.; UN Environment and German Development Institute: Geneva, Switzerland; Bonn, Germany, 2017; pp. 1-20.

86. EPA. Lean Manufacturing and the Environment; United States Environmental Protection Agency: Washington, DC, USA, 2003.

C 2020 by the authors. Licensee MDPI, Basel, Switzerland. This article is an open access article distributed under the terms and conditions of the Creative Commons Attribution (CC BY) license (http://creativecommons.org/licenses/by/4.0/). 